\title{
Brexit, Theresa May og de Tre Musketerer
}

\section{Af Mads Qvortrup}

David Cameron spillede højt spil - og tabte - da han i 2014 lovede en folkeafstemning om Brexit, hvis de Konservative vandt valget. $\mathrm{Nu}$ er det op til den ny premierminister, Theresa May, at indgå en aftale om udtræden af EU, der fortsat giver briterne adgang til det Indre Marked.

"Over 33 millioner vælgere i England, Skotland, Wales, Nordirland og Gibraltar har talt", sagde David Cameron, da han, klatøjet talte klokken 8:04 fredag den 24. juni. Fire timer inden var han blevet vækket af sin kabinetschef, Craig Oliver. Denne havde fortalt premierministeren at, "it's all over we have lost". 52 pct. havde stemt for at forlade EU.

Cameron stod straks op, tog et hurtigt brusebad og trak i sin mørkeblå habit. Den han har på til statsbegravelser. Kabinetschefen og premierministerens departementschef havde kun én rekommandation: gå. Og det gjorde Cameron så. Hans høje spil havde slået fejl. Han vidste, at han - med en til vished grænsende sandsynlighed - ville blive husket som en taber. Måske var det derfor, at hans stemme knækkede over, da han bekendtgjorde sin afgang klokken 8:06.
Kun ti timer tidligere havde det hele set meget anderledes ud. Cameron havde indbudt venner og bekendte til et middagsselskab i den officielle residensbolig i det berømte Downing Street nummer 10. Stemningen var munter. Hele London var i feststemning. Unge mennesker delte klistermærker ud med budskabet 'I'm In'. Der var en selvsikkerhed i luften, en følelse af at, ja, jovist havde valgkampen været hård, men i sidste ende var folket blevet overbevist om at forblive medlem af EU.

Hvis de unge mennesker, forretningsfolkene og de der drak cappuccino i hovedstadens italienske caféer, var en troværdig indikator, ville afstemningen blive vundet - og vundet klart. Men hvis de havde forladt hovedstaden og bevæget sig hinsides den store M25 omfartsvej og nedad M40 motorvejen til Oxford, ville de have set en plakat med den moderat fremmedfjendske overskrift: 'HALT ze German advance - Vote Leave!'

Budskabet var klart, forbliven i EU var ensbetydende med tysk dominans. Denne plakat og billboards med det besnærende simple - nogle ville sige overforsimplede - budskab, 'Take Back Control: Vote Leave!' prægede det grønne landskab.

Mads Qvortrup er professor i statskundskab ved Coventry University og forfatter til bogen 'Angela Merkel: Europe's Most Influential Leader' (Duckworth 2016). 
Hvis de unge mennesker, forretningsfolkene og de der drak cappuccino i hovedstadens italienske caféer, var en troværdig indikator, ville afstemningen blive vundet - og vundet klart.

Eliten i byerne var ude af trit med befolkningen som helhed.

\section{Taktisk spil}

Der er mange grunde til, at det gik som det gik. David Cameron havde aldrig regnet med, at der ville blive en folkeafstemning. Valgløftet om en Brexit-afstemning var blevet indføjet i de Konservatives valgprogram på et tidspunkt i 2014, hvor alt tydede på, at de Konservative ikke kunne vinde valget i 2015. Det var en taktisk manøvre med det ene formål at stække the United Kingdom Independence Party (UKIP), det yderligtgående højreorienterede parti, der truede de konservative ved ideligt at kræve en afstemning om EU medlemskab.

Dengang, i 2014-2015, tydede alt på, at Labours Ed Miliband ville blive den næste premierminister. Hvis det ikke skete, kunne David Cameron - i bedste fald - håbe på at indgå $\mathrm{i}$ en koalition med Liberal Demokraterne. Valgløftet kunne derefter blive droppet som en del af forhandlingerne. Cameron ville så kunne sige: “ja, jeg prøvede alt, men Liberal Demokraterne ville ikke have en folkeafstemning. Jeg beklager!". Elementært og ikke nogen dårlig logik, alt taget i betragtning.

Men sådan gik det som bekendt ikke.

Stik mod alle forventninger vandt de Konservative valget - om end med et snævert flertal, 330 ud af de 650 medlemmer.

Dette var problematisk af flere grunde. Primært fordi Cameron - for at undgå løftebrud - var tvunget til at holde en afstemning, og sekundært fordi mange - måske endog et flertal af hans nye parlamentskollegaer- var euroskeptikere; politikere, der havde mere til fælles med det højre-populistiske UKIP end med David Camerons liberale grundsynspunkter.

Med et så snævert flertal kunne politikere med stærke ideologiske og EU-skeptiske synspunkter gøre livet svært for Cameron. Nøjagtig som de havde gjort det for John Major - den konservative premierminister fra 1990-1997.

\section{Skuffede forventninger}

David Cameron - en mand der altid har bygget sin karriere på optimisme - troede, at de andre EU-lande ville være imødekommende. Han blev skuffet. Hans ønske om at indføre en begrænsning i antallet af østeuropæiske indvandrere blev blankt afvist - ikke mindst af Angela Merkel. På et besøg i London fortalte den magtfulde tyske Kanzlerin de britiske parlamentarikere: "Europa er ikke villig til at betale en hvilken som helst pris for at Storbritannien forbliver i EU". At Fru Merkel sagde disse ord på engelsk, mens resten af talen var holdt på tysk, siger meget.

Cameron fik - som forventet - ikke meget ud af forhandlingerne. Et løfte om at borgere fra andre EU-lande ikke i fremtiden kunne overføre børnepenge til afkom i deres hjemlande var overskriften. Det var et pauvert resultat. Men det bekymrede ikke premierministeren, endsige hans allierede. Lord Stuart Rose - formanden for den proeuropæiske kampagneorganisation Britain Stonger in Europe - forudså i februar 2016, at afstemningen "ville blive vundet med et klart flertal".

Om denne forudsigelse var baseret på politologiske granskninger eller blot et optimistisk gæt, må læseren vurdere. Denne 
På et besøg i London fortalte den magtfulde tyske Kanzlerin de britiske parlamentarikere: "Europa er ikke villig til at betale en hvilken som helst pris for at Storbritannien forbliver i Eป".

forfatter udgav få uger forinden i tidsskriftet Political Quarterly en videnskabelig artikel, som konkluderede, at "baseret alene på den statistiske model, vil den siddende regering tabe afstemningen med fire procent". Og sådan gik det som bekendt. Politik kan være en eksakt videnskab!

Hvorfor afstemningen blev tabt, og om Cameron kunne have vundet den, er et åbent spørgsmål. Det sandsynlige svar er negativt. Folkeafstemningen kom til at handle om immigration og national stolthed og ikke om økonomi, som Cameron havde håbet, ønsket og troet.

Cameron var ikke alene om at kæmpe for fortsat Britisk EU-medlemskab. De store banker - Lloyds TSB, The Royal Bank of Scotland, Barclays, advarede mod et 'leave', det samme gjorde nationalbanken, den Europæiske Centralbank, IMF, OECD og praktisk talt alle ledende nationaløkonomer.

\section{En fejltagelse}

Andrew Cooper - eller Lord Cooper - var David Camerons pollster; manden der lavede meningsmålinger for premierministeren, og som gav ham råd om den offentlige mening. Direkte adspurgt om årsagen til nederlaget sagde Lord Cooper:

"Vi tænkte på om vi kunne finde en formulering, som kunne imødekomme befolkningsflertallets bekymring over indvandringen, men vi kunne ikke finde noget, der kom i nærheden af, hvad de krævede".

Men Cooper indrømmede også fejltrin. Et af hovedargumenterne for dem, der ønskede at forblive medlemmer af EU - i det følgende Remain - var, at det ville være en $ø$ konomisk fordel at forblive en del af den Europæiske Union.

Det britiske finansministerium, HM Treasury, udarbejdede en rapport som angiveligt - viste, at hver enkelt hustand ville miste 4.000 pund per år i 2030, hvis Storbritannien ikke forblev medlem af Fællesskaberne. At sådanne økonometriske beregninger altid kommer med forbehold blev ikke overset af vælgerne.

"Set i bagspejlet var den rapport en fejltagelse", siger Lord Cooper. Noget overraskende indrømmede han også, at Remain "ikke havde testet det økonomiske budskab i fokusgrupper".

\section{'Leave'}

På den modsatte fløj så det ikke umiddelbart lyst ud. Organisationen Vote Leave, med Londons borgmester Boris Johnson og justitsminister Michael Gove i spidsen, konkurrerede med UKIP- lederen Nigel Farrages Leave.eu. Men trods dette formåede de to grupper at appellere til det samme publikum med dels deres 'take back control'-slogan - og med et argument om, at man hver uge betalte 350 millioner pund til EU.

Det blev af tilhængerne sagt, at dette tal var fantasifuldt. Var det? Hvert land betaler 1,04 pct. af deres BNP til EU. Da det årlige BNP er 2849 milliarder US dollar - er tallet ikke helt så fantasifuldt, som først antaget, men slige tal forvirrer mere end de hjælper. Det blev Cameron og Remains problem igennem valgkampen.

"Vælgerne internaliserede modstandernes påstande, når vi spurgte dem i fokus- 
grupper", fortalte Lord Cooper til citat til denne artikels forfatter. Det overraskende var ikke, at Cameron tabte, men at nederlaget ikke blev større.

\section{Tiden der fulgte}

I dagene umiddelbart efter folkeafstemningen faldt pundet. Mange af tilhængernes forudsigelser og dommedagsprofetier blev indfriet. Som følge af den ti pct. devaluering, der ramte pundet, var Storbritanniens BNP mindre end Frankrigs kun tolv timer efter, at resultatet var blevet offentliggjort.

Mark Carney - den canadiskfødte direktør for Bank of England - blev stillet skoleret foran Underhusets finansudvalg, men gentog kun sin påstand fra inden afstemningen. Han havde gjort sin pligt og advaret. Og han havde fået ret.

Gik det så galt som frygtet?

Små to måneder senere viste de første $ø$ konomiske indikatorer, at Storbritannien ikke var ramt af en recession, som ellers forudset af mange økonomer - inklusive Carney. Det lavere pund havde stimuleret eksporten. Men det betød ikke, at faren var overstået. Eller, som ugemagasinet The Economist skrev i begyndelsen af september, "dommedagsprofetierne er ikke blevet indfriet - ikke endnu".

At folkeafstemningsresultatet også havde politiske implikationer talte færre om. Det faktum, at et flertal på 62 pct. i Skotland stemte for forbliven i EU betød, at det regerende Scottish National Party begyndte at tale om en ny folkeafstemning om selvstændighed (55 pct. havde stemt imod selvstændighed i en afstemning i 2014).

\section{Politisk kaos}

Formalia skal være i orden. For at forlade EU skal et land formelt ansøge de andre lande herom, efter en procedure der er omtalt i Artikel 50 i Lissabon-traktaten. Men den britiske regering havde ikke hastværk.

Det skyldtes mest af alt det totale politiske kaos, der eksisterede efter afstemningen. Efter Camerons afgang begyndte de Konservative at lede efter en ny leder. Og for at gøre billedet komplet stemte et flertal af de menige parlamentsmedlemmer af oppositionspartiet Labour for en mistillidsdagsorden mod lederen Jeremy Corbyn. Den venstreorienterede leder - der havde været modstander af EU så sent som 1990'erne hvor han stemte imod Maastricht-traktaten - havde været lunken i sit forsvar for fortsat britisk medlemskab.

At hans synspunkter om nationalisering, fagforeningers rettigheder og forsvarspolitik er tættere på den politik, som forfægtes af Enhedslisten i Danmark og Die Linke i Tyskland end på de socialdemokratiske idealer, som Labour traditionelt har repræsenteret, var en anden årsag til mistilliden. Mange af Labours medlemmer og stort set alle politiske kommentatorer mener, at det hæderkronede arbejderparti er dømt til at tabe næste valg, hvis Corbyn forbliver ved magten. Det er i skrivende stund ikke afgjort om han kan forblive formand for Labour.

Umiddelbart efter folkeafstemningsresultatet brød krigen ud i The Conservative and Unionist Party - som de Konservative officielt hedder. Favoritten var Boris Johnson - der indtil en måned forinden havde været borgmester i London. (Han stillede ikke op til genvalg til borgmesterposten, da han allerede havde siddet $i$ to valgperioder).

Manden som ofte blev kaldt The Clown Prince of the Conservative Party havde gennem hele folkeafstemningen været talsmand for EU-modstanderne. Hans argumentation - hvis dette ord giver mening 
- var baseret på slogans og hans uomtvistelige star quality.

Selvom Boris - alle er på fornavn med ham! - taler med overklasseaccent, er han på paradoksal vis en mand af folket. Den tidligere EU-korrespondent for den højreorienterede avis The Daily Telegraph læste klassisk filologi i Oxford og formulerer sig stundom på latin. Og alligevel - eller måske netop af den grund - er han elsket af mange. I de første dage var Boris Johnsons kandidatur støttet af justitsminister Michael Gove. De to havde - som nævnt kæmpet på samme side under folkeafstemningen.

\section{Konservativt magtspil}

Ud over Johnson kastede andre EU-modstandere deres hat i ringen; henholdsvis den tidligere forsvarsminister Dr. Liam Fox (en tidligere skotsk militærlæge med højresnoede synspunkter) og Andrea Leadsom. Sidstnævnte havde været et ubeskrevet blad indtil afstemningen. Den bramfri husmoder - der angiveligt havde arbejdet i en ledende stilling i finanssektoren - var blevet landskendt under afstemningen. Dette til trods var Boris Johnson den klare favorit.

Blandt tilhængerne var indenrigsminister Theresa May den eneste, der havde en realistisk chance. Den anden EU-tilhænger, der stillede op, var socialminister Stephen Crabb.

Alle regnede med at Boris Johnson ville eliminere de andre kandidater. Men formelt havde Johnson ikke erklæret at han var kandidat.

30. juni var den officielle slutdato for po- tentielle kandidater. Alle - inklusive denne forfatter - troede, at Boris Johnson ville erklære sit kandidatur kort før deadline. Det gjorde han ikke. Dagen inden mødtes Boris Johnson med Michael Gove. Sidstnævnte ønskede en garanti for, at han ville blive finansminister i en regering ledet af førstnævnte. Johnson ville ikke give denne garanti.

Gove blev sur. Hans kone Sarah Vine en klummeskriver ved den højreorienterede avis The Daily Mail - overbeviste som en anden Lady Macbeth sin ægtefælle om at stille op. Det gjorde Gove. Til alles overraskelse erklærede han, at han - efter moden overvejelse, det vil sige i realiteten en ti minutters samtale med fruen - havde besluttet sig til stille op, da Johnson ikke var en seriøs politiker.

Gove insinuerede også, at Johnson havde et privatliv og en livsstil, der - for nu at formulere det diplomatisk - ikke var foreneligt med posten som premierminister.

Med ét slag kollapsede Boris Johnsons ambitioner. Hans far - Stanley Johnson responderede med at citere Cæsars "et tu me Brute filiae" - også du min søn Brutus. Boris Johnson holdt den planlagte pressekonference, men sluttede med at sige, at han ikke var kandidat.

Hvis Gove havde troet, at han qua EU-modstand kunne overbevise sine parlamentskollegaer om, at han skulle være Camerons efterfølger, så tog han fejl. Efter at Dr. Fox og Stephen Crabb var blevet elimineret, stod Gove for tur. Som Brutus i det gamle Rom måtte også Gove sande, at den, der fører kniven, sjældent bliver kejser.

Som Brutus i det gamle Rom måtte også Gove sande, at den, der fører kniven, sjældent bliver kejser. 


\section{En kamp mellem to kvinder}

De to sidste kandidater til posten var begge kvinder; Theresa May og Andrea Leadsom. For første gang siden Margaret Thatcher (1979-1990) ville Storbritannien blive ledet af en kvinde.

Hidtil havde kun parlamentsmedlemmerne kunnet stemme. Men hvem af de to kandidater, der ville efterfølge Cameron, skulle afgøres af de menige partimedlemmer.

Det gav Leadsom en chance. De fleste partiforeninger og deres medlemmer var til højre for parlamentarikerne og er notorisk EU-skeptiske. At disse skulle stemme for en EU-tilhænger som Theresa May virkede naturstridigt.

Men problemet for Andrea Leadsom var manglende erfaring. Det blev afgørende. Hun havde hidtil hævdet, at hun havde haft en ledende stilling i erhvervslivet, og at hun havde arbejdet som direktør i flere store banker. Men ingen i de store banker kunne huske hende. Og en journalist med it-indsigt fandt ud af, at fru Leadsom angiveligt havde pyntet på sit CV ved at redigere teksten på sin egen Wikipediaside.

Leadsom havde nok arbejdet i finanssektoren, men havde været ansat i en underordnet funktionærstilling, og hun havde aldrig været fundmanager, som hendes CV hævdede. Om dette betød meget for de menige partimedlemmer er svært at sige, men det hjalp ikke Leadsom.

At være en succesfuld politiker handler også om at have takt, om at kunne glide af på spørgsmål og om at kunne holde kæft, når man bliver provokeret.

Leadsom havde konsekvent fremstillet sig selv som 'Mor, bedstemor og forretningskvinde’.

At hendes karriere i erhvervslivet havde været mindre glorværdig end først antaget betød, at hun nu konstant henviste til, at hun havde fire børn, og at hun i øvrigt lige var blevet farmor. Det appellerede til de menige partimedlemmer - der mestendels er over de tres. Men denne promovering af mor- og bedstemorrollen var også en slet skjult henvisning til, at Theresa May - selvom hun er gift - ikke har børn.

Det var helt efter bogen, at avisen The Times spurgte, om det var diskvalificerende for Theresa May, at hun ikke var mor. Leadsom - der burde havde vidst bedre svarede at "man ikke kan have den samme følelse af forpligtelse for efterfølgende generationer, hvis man ikke har været mor".

At en sådan udtalelse var dybt sårende og usympatisk er selvsagt. At Leadsom hævdede, at hun var fejlciteret, gjorde det ikke bedre - især ikke da The Times offentligjorde hele samtalen. To dage efter interviewet trak Leadsom sig.

\section{Tronskiftet}

Theresa May var nu blevet ny formand for de Konservative uden at en eneste stemme var blevet afgivet.

Tronskiftet skete i huj og hast den 13. juli. I løbet af få timer var David Cameron ude af Downing Street 10, og Theresa May var flyttet ind. Cameron forsøgte i sin aftrædelsestale at sige, at han havde opnået meget - blandt andet at han havde indført en lov om homofile vielser - men han glemte at sige, at denne ikke omfatter den anglikanske kirke, og at så mange af hans ærkekonservative partifæller havde stemt imod, at loven kun blev vedtaget med Labours stemmer.

Selv aviser der havde støttet ham, omtalte Cameron som en taber. The Financial Times, for blot at nævne et enkelt eksempel, beskrev Camerons beslutning om at holde en folkeafstemning som "den største politiske katastrofe i efterkrigstiden".

Theresa May handlede hurtigt. Og tog 
Selv aviser der havde støttet ham, omtalte Cameron som en taber. The Financial Times, for blot at nævne et enkelt eksempel, beskrev Camerons beslutning om at holde en folkeafstemning som "den største politiske katastrofe i efterkrigstiden".

overraskende beslutninger. Hun fyrede den hidtidige finansminister George Osborne og indsatte den lidt grå Phillip Hammond på posten. Sidstnævnte, der tidligere havde været udenrigs-, forsvars- og trafikminister, var i det private en relativt succesfuld iværksætter fra den lavere middelklasse. Osborne - eller, som han var døbt, Sir Gideon Osborne - var adelig, havde gået på privatskole og var en typisk repræsentant for den nu hensygnende Cameron-epoke.

Mest overraskende af alt udnævnte May hele tre ministre til at føre forhandlingerne om Brexit. Alle tre var EU-modstandere, henholdsvis Boris Johnson som udenrigsminister, Liam Fox som handelsminister og David Davies som minister for Brexit.

At ingen af disse tre mænd kan holde hinanden ud er måske sigende for Theresa Mays taktiske sans.

\section{Hovedpersonen}

For at forstå de politiske udsigter i Storbritannien kan det være nyttigt at se lidt nærmere på de dramatis personae, der vil spille hoverrollerne i den fortsatte fortælling om Brexit. Det er indlysende at begynde med hovedpersonen, Theresa May.

Det var ikke overraskende, at den 59-årige politikers første handling var at rejse til Berlin. EU er muligvis et fællesskab, men der er én politiker, der mere end nogen anden træffer de vigtige beslutninger. Det er Angela Merkel.

Nogle i de britiske medier har sammenlignet Theresa May med den tyske kansler. Det er ikke uden grund. Inden deres møde i midten af juli sagde Merkel "Jeg er overbevist om at vi to præstedøtre vil komme godt ud af det med hinanden".
At May lige som Merkel er vokset op i et protestantisk præstehjem, og at ingen af de to kvinder har børn eller er overbebyrdede af traditionel karisma, har været meget omtalt. En anden og måske mere væsentlig fællesnævner er, at de begge er steget til tops i konservative partier, der traditionelt har været domineret af mænd.

Men der er en forskel. Tyskland er ikke et klassesamfund som Storbritannien. I britisk politik - især under Cameron - har landet været regeret af kostskoleuddannede mænd med mere eller mindre adelig baggrund som Cameron, George Osborne og den liberale leder Nick Clegg.

Theresa May er en udpræget middelklassekvinde. Efter at have afsluttet en middelmådig bachelorgrad i geografi i Oxford, arbejdede hun i en underordnet stilling i finanssektoren. Efter at være blevet valgt til parlamentet i 1997 steg May i rækkerne, og hun blev i 2001 forfremmet til generalsekretær for de Konservative. I denne rolle ryddede hun op og reformerede en partiorganisation, der var præget af ultraliberale ideologer. Hendes erklæring i 2002 om at de konservative blev opfattet som 'the nasty party' - frit oversat 'det lede parti' - skabte respekt. Det er altid et tegn på politisk mod at gå imod sine egne.

Efter valget i 2010 blev hun indenrigsminister, og selvom hun ikke formåede at formindske antallet af asylansøgere og indvandrere, blev hun opfattet som en kompetent politiker, en der kender sit ressortområde.

Men hvad der måske er mere interessant er, at hun - og hendes tro rådgiver Nick Timothy - har en politisk filosofi og et forbillede. Margaret Thatcher sværmede for den 
østrigsk fødte økonom Friedrich Hayek. Theresa May citerer gerne Joseph Chamberlain (1936-1914). Det er ikke overraskende, Chamberlain - der var borgmester i Birmingham i slutningen af det 19. århundrede - var en politiker, der ikke kom fra overklassen. Han var en forrentningsmand, der gik ind i politik.

Chamberlain var fortaler for sociale reformer og bidrog til at der blev indført et offentligt skolevæsen, som arbejderklassen havde gratis adgang til. Og som landspolitiker var Chamberlain modstander af irsk selvstændighed. At Theresa May ofte fremhæver, at hun er imod skotsk selvstændighed er ikke overraskende.

Men mere væsentligt var Joseph Chamberlain ikke tilhænger af frihandel. Han ønskede et nærmere handelssamarbejde med kolonierne. Imperiet er forsvundet for mange årtier siden, men mange briter har et emotionelt bånd til andre Commonwealth-lande. At Theresa May - i det omfang hun har udtalt sig konkret - også har talt om at indgå aftaler med Canada, Indien og Australien efter Brexit kunne tyde på, at hun har nærlæst sit ideologiske forbillede.

\section{De tre musketer}

'Én mod alle - alle mod én'. Det er nærliggende at fejlcitere Alexandre Dumas' musketered i forbindelse med det triumvirat, der officielt skal forhandle Brexit på plads. Udenrigsminister Boris Johnson, handelsminister Liam Fox og Brexit-minister David Davies er tre musketerer, der ikke viser hinanden megen hengivenhed eller solidaritet. De tre deler en fælles embedsbolig, Chevening House, i Kent sydøst for London. Omend 'huset' er et palads med 115 værelser, muntrer medierne sig ofte over 'The Chevening Three' og deres problemer med at komme overens.
At Boris Johnson blev udenrigsminister var af mange opfattet som noget nær en hån mod resten af Europa. "Han er ikke nogen seriøs politiker", sagde den tyske udenrigsminister Frank-Walter Steinmeier til citat efter udnævnelsen. Hans franske kollega Jean-Marc Ayrault var endnu mindre diplomatisk: "Boris er en løgner. Han løj over for det britiske folk, og nu har han ryggen mod muren".

\section{Nogle i de britiske medier har sammenlignet Theresa May med den tyske kansler. Det er ikke uden grund. Inden deres møde i midten af juli sagde Merkel "Jeg er over- bevist om at vi to præstedø- tre vil komme godt ud af det med hinanden".}

I realiteten er Boris Johnson ikke den væsentligste politiker. Udenrigsministeriet er kun i begrænset grad involveret i Brexit-forhandlingerne. Forhandlingerne om briternes skilsmisse fra EU bliver varetaget af David Davies. Og forhandlingerne om handelsaftaler med tredjelande er Liam Fox' ressort. I praksis er Boris Johnsons rolle indskrænket til at omhandle OSCE-møder og de sikkerhedspolitiske spørgsmål, der ikke allerede henhører under forsvarsminister Michael Fallons ressort.

Ved at udnævne Johnson til udenrigsminister har May sikret sig, at en mulig konkurrent konstant er på rejse men uden et egentligt betydningsfuldt job.

I den første måned efter May kom til magten, har David Davies og Liam Fox ført en ihærdig kamp. De kappes om hvilke embedsmænd, der skal overføres fra Udenrigsministeriet til henholdsvis Brexit-ministeriet og til det nye Handelsministerium. Det har været en bitter kamp. Den foregår fortsat. 
Det er også meningen. Ved at udnævne tre modstandere af EU til at forhandle om Storbritanniens udtræden af EU har hun ført en klassisk del og hersk-politik.

Resultatet af denne taktiske manøvre er, at det i dagligdagen er finansminister Phillip Hammond, der har mest indflydelse over Brexit-forhandlingerne. Og, hvad der ikke er mindre væsentligt, ved at henvise til uenigheden mellem 'The Chevening Three' har May en god undskyldning for selv at lede forhandlingerne.

\section{En vanskelig opgave}

Man kan mene meget om Theresa May. Mange har undervurderet hende, og nogle har sagt, at hun ikke har megen udenrigspolitisk erfaring. Det samme blev sagt om Angela Merkel i 2005.

Om May formår at indgå en aftale om udtræden af EU, der giver briterne adgang til det Indre Marked uden at betale for det og uden at acceptere indvandring, er et åbent spørgsmål. Merkel har sagt, at hun ikke kan acceptere 'Rosinenpickerei'; og Mays erklæring om, at 'Brexit betyder Brexit' tyder på, at briternes nye premierminister er villig til at se realiteterne i øjnene.

At forhandlingerne med EU kun er en del af en ligning med mange ubekendte og at Mrs. May også skal overbevise skotterne om at forblive en del af The United Kingdom - betyder, at den nye premierminister har en vanskelig opgave foran sig. "Jeg har ikke karisma, men jeg kan løse problemer", sagde Theresa May, da hun stillede op til formandsposten. De næste to år vil vise om hun har ret; om hun kan løse problemer. 